\title{
ZASADA ZRÓWNOWAŻONEGO ROZWOJU JAKO DYREKTYWA DZIAŁAŃ ADMINISTRACJI PUBLICZNEJ
}

Wielokrotnie w przestrzeni publicznej można zauważyć, usłyszeć o działaniach podejmowanych na rzecz zrównoważonego rozwoju. Słyszy się również o warsztatach dotyczących zrównoważonego rozwoju, ekorozwoju oraz wielu innych przedsięwzięciach.

Można przyjąć, że zasada zrównoważonego rozwoju często determinuje podejmowanie określonych działań czy przez administrację publiczną, czy przez inne podmioty. W związku z tym należy przyjąć, że zasada ta stanowi pewną dyrektywę działań administracji publicznej. Poprzez tę pracę pragnę wskazać, że rzeczywiście tak jest, że zasada zrównoważonego rozwoju wyznacza kierunki rozrostu społeczno-gospodarczego.

Aby móc wskazać, w jaki sposób omawiana zasada wpływa na działania podejmowane przez administrację publiczną, należy dogłębnie poznać i dowiedzieć się, czym jest i do czego się odnosi zasada zrównoważonego rozwoju.

Na wstępie trzeba zauważyć, że to ta zasada, od drugiej połowy XX w., ma znaczący wpływ na sposób postrzegania relacji występujących między gospodarką, środowiskiem a społeczeństwem. ${ }^{1} \mathrm{~W}$ latach 60 . i 70. XX w. zauważono, że rozwój społeczeństw, przemysłu, wzrost konsumpcji, a także produkcji, nadmiernie wpływa na eksploatację zasobów naturalnych. Wskazywano, że wymienione sytuacje stanowią pewne zagrożenie dla środowiska. Zaobserwowanie tych zjawisk stało się przyczyną sporządzenia w 1969 r. raportu pt. „Człowiek i jego środowisko” przez sekretarza ONZ - U Thanta. Dokonano w nim charakterystyki najistotniejszych zagrożeń środowiska naturalnego o charakterze globalnym. ${ }^{2} \mathrm{O}$ zagrożeniach tych deliberowano trzy lata później, w 1972 r., podczas konferencji Organizacji Narodów Zjednoczonych w Sztokholmie. Podczas tego spotkania po raz pierwszy użyto pojęcia „ekorozwój”. Pojęcie to zostało sprecyzowane na kolejnej, III Sesji Zarządzają-

\footnotetext{
1 E. Mazur-Wierzbicka, Ochrona środowiska a integracja europejska: doświadczenia polskie, Warszawa 2012, s. 46. 2 Ibidem.
} 
cej Programem Ochrony Środowiska ONZ. Przyjęto wówczas, że ekorozwój to „taki przebieg rozwoju gospodarczego, który nie narusza w sposób istotny i nieodwracalny środowiska życia człowieka, godząc prawa przyrody i prawa ekonomii”. ${ }^{3} \mathrm{Bez}-$ pośrednio powyższe akty odnosiły się do koncepcji zrównoważonego rozwoju.

Pojęcie zrównoważonego rozwoju użyte zostało po raz pierwszy na arenie międzynarodowej przez Międzynarodową Unię Ochrony Przyrody, natomiast zostało wprowadzone do powszechnego użycia przez Raport „Nasza Wspólna Przyszłość” z 1987 r. (tzw. Raport Brundtland). W raporcie tym po raz pierwszy doszło do oficjalnego zdefiniowania pojęcia zrównoważonego rozwoju. Wskazano, że ,zrównoważony rozwój to rozwój zgodny z potrzebami obecnych pokoleń, nie umniejszający możliwości przyszłych pokoleń do zaspokajania swoich potrzeb". ${ }^{4}$ We wspomnianym raporcie można również dowiedzieć się tego, że „zrównoważony rozwój jest procesem zmian, w którym wykorzystywanie zasobów, kierunki inwestycji, orientacja rozwoju technologicznego i instytucjonalnych zmian są ze sobą zgodne w zaspokajaniu przyszłych i obecnych potrzeb". "Zasygnalizowano w nim także potrzebę uwzględniania $\mathrm{w}$ rozwoju społeczno-ekonomicznym ochrony środowiska. ${ }^{6}$ Aby wdrożyć nowo zdefiniowaną zasadę, przyjęto szereg zaleceń. Wynika z nich konieczność podejmowania działań w taki sposób, aby m.in. eksploatować odnawialne zasoby przyrody w taki sposób, aby nie przekraczać tempa ich naturalnej odnowy, dokonywać takiej kalkulacji korzystania z zasobów nieodnawialnych, która pozwoli z nich korzystać do chwili powstania ich substytutów, rozsądnie rekultywować ziemię, minimalizować negatywne oddziaływanie na powietrze, wodę i inne elementy środowiska w sposób nienaruszający integralności systemu. ${ }^{7} \mathrm{Z}$ zaproponowanych działań wynika, że zasada zrównoważonego rozwoju miała wpływ na podejmowanie określonych aktywności już od początku jej zainicjowania.

Kolejnym istotnym wydarzeniem w kształtowaniu koncepcji zrównoważonego rozwoju była konferencja zainicjowana przez ONZ w Rio de Janeiro w 1992 r. - „Szczyt Ziemi”. Uczestnicy konferencji przyjęli szereg zasad i zadań mających na celu ochronę środowiska i rozwoju ekonomicznego w duchu zasady zrównoważonego rozwoju. Podczas „Szczytu Ziemi” przyjęto m.in. Deklarację w sprawie środowiska i rozwoju, w której zapisano 27 zasad ogólnych korzystania ze środowiska naturalnego. Zaakceptowano także Agendę 21 - programowy dokument zawierający konkretne działania na rzecz zrównoważonego rozwoju w skali globalnej. ${ }^{8}$

Wskazane wydarzenia przyczyniły się do powstania koncepcji, zasady zrównoważonego rozwoju, którą początkowo odnoszono jedynie do działań o charakterze ogólnoświatowym, globalnym, makroekonomicznym. Dopiero po pewnym czasie

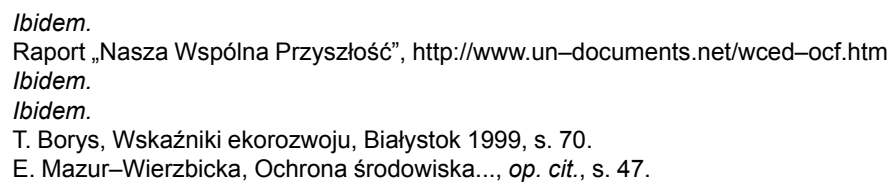


zaczęto wskazywać płaszczyznę mikroekonomiczną, tj. miasta, przedsiębiorstwa, jako tę, która także ma realny wpływ na realizację omawianej zasady. ${ }^{9}$

Nawet po przedstawieniu w skrócie ewolucji koncepcji zrównoważonego rozwoju widać, że stanowi ona pewną dyrektywę działań podmiotów publicznych i nie tylko. Wdrażanie ogólnych zaleceń przełożyło się i nadal przekłada na konkretne, realnie podejmowane aktywności.

Zasada zrównoważonego rozwoju jest zasadą ogólną, która coraz bardziej zyskuje na popularności. Tworzonych jest wiele jej definicji i wyjaśnień. Niektóre z nich zaprezentowane zostaną poniżej.

Prof. M.K. Byrski statuuje, że zrównoważony rozwój to pewien wzorzec, którego celem jest zapewnienie godziwego bytu wszystkim mieszkańcom ziemi. Prof. F. Piontek wskazuje, że „rozwój zrównoważony polega na kształtowaniu właściwych proporcji w angażowaniu poszczególnych rodzajów kapitału uprzedmiotowionego, ludzkiego i przyrodniczego". Prof. W. Bojarski odnosi omawiany rozwój do takiego rozwoju społeczno-gospodarczego, który jest zharmonizowany ze środowiskiem naturalnym, przyrodniczym. Natomiast prof. M. Burchard-Dziubińska uznaje zrównoważony rozwój za wspólny rozwój systemu gospodarczego, społecznego i przyrodniczego, który to rozwój ma gwarantować pozostawanie w harmonii w sposób w pełni chroniący bioróżnorodność. ${ }^{10}$

W polskim porządku prawnym zasadę zrównoważonego rozwoju statuuje Konstytucja Rzeczypospolitej Polskiej w art. 5. Z przepisu tego wynika, że Rzeczpospolita Polska, przy przedsiębraniu pewnych działań, czynności, musi się kierować omawianą zasadą. ${ }^{11}$ Prof. B. Banaszak, konstytucjonalista, wyjaśnia, że zasada ta oznacza „konieczność znajdowania takich rozwiązań technicznych, organizacyjnych, prawnych itp. sprzyjających rozwojowi ekonomicznemu, czy szerzej, cywilizacyjnemu, które pozwolą chronić środowisko naturalne". ${ }^{12}$

Prof. P. Sarnecki, na podstawie Konstytucji RP, wskazuje, że zasada zrównoważonego rozwoju „krępuje” wszelkie działania dotyczące ingerencji w środowisko przyrodnicze. ${ }^{13}$ Zauważa, że wszędzie tam, gdzie miałoby dochodzić do ingerencji w środowisko, należy dbać nie tylko o to, aby ingerencja ta była jak najmniejsza (najmniej szkodliwa), lecz by osiągane korzyści społeczne były co najmniej proporcjonalne, społecznie adekwatne do strat, jakie się wówczas ponosi”. ${ }^{14}$

Zasada zrównoważonego rozwoju jest pojmowana także jako powiązanie szybkiego rozwoju gospodarczego, wzrostu jakości życia społeczeństw z poprawą stanu środowiska naturalnego. Aby to osiągnąć, państwo jest zobligowane do „zachowania różnorodności biologicznej i możliwości odtwarzania się zasobów naturalnych,

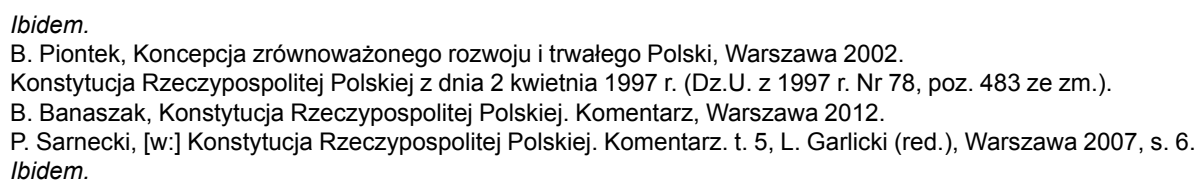


rozwoju proekologicznych technologii, racjonalnego kształtowania środowiska poprzez m.in. ograniczanie różnych uciążliwości dla środowiska". ${ }^{15}$

Również w polskich aktach prawnych rangi ustawowej znajduje się legalna definicja „zrównoważonego rozwoju”. Poprzez zrównoważony rozwój, zgodnie z art. 3 pkt 50) ustawy Prawo ochrony środowiska, rozumie się „,taki rozwój społecznogospodarczy, w którym następuje proces integrowania działań politycznych, gospodarczych i społecznych, z zachowaniem równowagi przyrodniczej oraz trwałości podstawowych procesów przyrodniczych, w celu zagwarantowania możliwości zaspokajania podstawowych potrzeb poszczególnych społeczności lub obywateli zarówno współczesnego pokolenia, jak i przyszłych pokoleń". ${ }^{16}$ Definicja ta określa przedmiotowy rozwój jako „specyficzny rozwój społeczno-gospodarczy, z określonym celem i o oznaczonym charakterze. Jego celem jest zagwarantowanie możliwości zaspokajania podstawowych potrzeb przez ludzi. Wskazuje to na całkowicie antropocentryczny charakter zrównoważonego rozwoju". ${ }^{17}$ Natomiast kwintesencją zrównoważonego rozwoju jest to, że integruje ona zarówno sferę polityki, gospodarki, jak i działań społecznych z elementarnymi wymaganiami środowiska przyrodniczego. ${ }^{18}$

Mając na uwadze wskazane definicje, nie sposób nie wyciągnąć kilku wniosków dotyczących zasady zrównoważonego rozwoju. Po pierwsze, istnieje ścisła zależność między stanem środowiska, zaspokajaniem potrzeb a jakością życia teraźniejszych i przyszłych pokolenn. ${ }^{19}$ Po drugie, ,zrównoważony rozwój [...] prowadzi do zapewnienia odpowiednio wysokich standardów ekonomicznych, ekologicznych i społecznych zarówno obecnym, jak i przyszłym pokoleniom". ${ }^{20}$

Obowiązkiem władz publicznych, płynącym z Konstytucji RP, z ustawy Prawo ochrony środowiska i z prawa międzynarodowego, jest kształtowanie działalności w taki sposób, aby wykonywane zadania były odzwierciedleniem zasady zrównoważonego rozwoju.

Polska, spełniając postanowienia wynikające z zaleceń kierowanych przez międzynarodowe organizacje, takie jak ONZ, z prawa międzynarodowego, prawa Unii Europejskiej, uchwaliła szereg ustaw, które mają nakierować konkretne organy administracji publicznej na podejmowanie działań zgodnie z koncepcją zrównoważonego rozwoju.

Aby potwierdzić tezę, że zasada zrównoważonego rozwoju stanowi dyrektywę działań administracji publicznej, wskażę przykładowe akty prawne.

\footnotetext{
15 S. Grabowska, R. Grabowski, W. Skrzydło, Konstytucja RP: komentarz encyklopedyczny, Warszawa 2009, s. 728 .

Ustawa z dnia 27 kwietnia 2001 r. - Prawo ochrony środowiska (Dz.U. z 2008 r. Nr 25, poz. 150).

J. Jendrośka, Leksykon prawa ochrony środowiska, Warszawa 2012, s. 193.

Ibidem.

B. Piontek, Koncepcja zrównoważonego..., op. cit., s. 15.

E. Mazur-Wierzbicka, Ochrona środowiska..., op. cit., s. 51.
} 
Jak już zostało wspomniane, Konstytucja RP w art. 5 stwierdza, że Polska podejmuje działania kierując się zasadą zrównoważonego rozwoju, a więc zasada ta została podniesiona do rangi zasad konstytucyjnych. ${ }^{21} \mathrm{Z}$ art. 74 Konstytucji RP wynika natomiast obowiązek ochrony środowiska oraz prowadzenia takiej polityki, która zapewni bezpieczeństwo ekologiczne obecnym, jak i przyszłym pokoleniom. ${ }^{22}$ Zestawiając przytoczone przepisy z art. 86 Konstytucji RP, które statuują obowiązek dbania o środowisko, można zauważyć, że już na gruncie Konstytucji RP - ustawy zasadniczej - zasada zrównoważonego rozwoju wyznacza kierunki podejmowanych przedsięwzięć przez organy administracji publicznej.

Przechodząc do kolejnych przykładów ustaw na organy administracji publicznej w przedmiocie realizacji zasady zrównoważonego rozwoju należą ustawy tzw. ustrojowe - ustawa o samorządzie gminnym, ustawa o samorządzie powiatowym oraz o samorządzie województwa.

Ustawa o samorządzie gminnym $\mathrm{w}$ art. 7 zawiera katalog zadań własnych gminy. ${ }^{23}$ Wynika $z$ niego, że gmina jest zobowiązana do podejmowania czynności na rzecz $\mathrm{m}$.in. ładu przestrzennego, ochrony zdrowia, a także na rzecz ochrony przyrody i ochrony środowiska. ${ }^{24}$ Mając na uwadze, że zrównoważony rozwój dotyczy współdziałania np. gospodarki, środowiska i społeczeństwa, a do zadań gminy należą także sprawy związane $\mathrm{z}$ wodociągami i zaopatrzeniem w wodę, kanalizacją, usuwaniem i czyszczeniem ścieków komunalnych, należy zgodzić się ze stwierdzeniem prof. Ciechanowicz-McLean, że większość zadań gminy ma decydujące znaczenie dla realizacji zasady zrównoważonego rozwoju. ${ }^{25}$

Podobnie zadania przedstawiają się w samorządzie powiatowym. Ustawa o samorząadzie powiatowym w art. 4 wskazuje, że do zadań własnych powiatu należy zarówno ochrona środowiska, jak i ochrona przyrody, a także zadania publiczne o charakterze ponadgminnym w zakresie m.in. gospodarki wodnej, rolnictwa, leśnictwa i rybactwa śródlądowego. ${ }^{26}$ Również i do organów samorządu powiatowego należy odnieść stanowisko prof. Ciechanowicz-McLean.

Samorząd województwa natomiast, w zakresie kierowania się zasadą zrównoważonego rozwoju, w art. 11 określa strategię rozwoju województwa, uwzględniając pobudzanie aktywności gospodarczej, podnoszenie innowacyjności gospodarki województwa, kształtowania i utrzymania ładu przestrzennego, zachowując wartości środowiska przyrodniczego w odniesieniu do potrzeb przyszłych pokoleń. ${ }^{27} \mathrm{Na}$ politykę rozwoju województwa prowadzoną przez samorząd województwa składa się także racjonalne korzystanie z zasobów przyrody oraz kształtowanie środowi-

Konstytucja Rzeczypospolitej Polskiej z dnia 2 kwietnia 1997 r. (Dz.U. z 1997 r. Nr 78, poz. 483 ze zm.).

Ibidem.

Ustawa z dnia 8 marca 1990 r. o samorządzie gminnym (Dz.U. z 2013 r., poz. 153).

Ibidem.

J. Ciechanowicz-McLean, Prawo i polityka ochrony środowiska, Warszawa 2009, s. 156.

Ustawa z dnia 5 czerwca 1998 r. o samorządzie powiatowym (Dz.U. z 2011 r. Nr 217, poz. 1281).

Ibidem. 
ska naturalnego przy uwzględnieniu zasady zrównoważonego rozwoju ${ }^{28}$ Samorząd województwa jest zobligowany do prowadzenia takich działań, które będą uwzględniały potrzeby obecnych i przyszłych pokoleń w zakresie gospodarki, środowiska, przyrody.

Nie sposób nie zwrócić uwagi na ustawę o odpadach. Ustawa ta określa środki, które mają stosować określone organy. Środki te mają na celu ochronę środowiska, zdrowia, życia, a także zapobieganie oraz zmniejszanie negatywnego wpływu na środowisko naturalne..$^{29}$ Posługując się określonymi środkami, organy wypełniają zadania wynikające z koncepcji zrównoważonego rozwoju.

Wypełniając postanowienia kolejnej ustawy - ustawy o lasach, organy również stosują zasadę zrównoważonego rozwoju. W ustawie tej jest mowa o trwale zrównoważonej gospodarce leśnej. Zgodnie z art. 6 ust. 1 pkt 1a), poprzez to pojęcie należy rozumieć działalność zmierzającą do ukształtowania struktury lasów i ich wykorzystania w sposób i tempie zapewniającym trwałe zachowanie ich bogactwa biologicznego, wysokiej produkcyjności oraz potencjału regeneracyjnego, żywotności i zdolności do wypełniania, teraz i w przyszłości wszystkich ważnych ochronnych, gospodarczych i socjalnych funkcji na poziomie lokalnym, narodowym i globalnym, bez szkody dla innych ekosystemów. ${ }^{30}$

Natomiast ustawa Prawo wodne expressis verbis wskazuje, że wszelkie kształtowanie i ochrona zasobów wodnych, ich zarządzanie, a także korzystanie z wód musi się odbywać zgodnie z zasadą zrównoważonego rozwoju. ${ }^{31}$

$\mathrm{W}$ ustawie o udostępnianiu informacji o środowisku i jego ochronie, udziale społeczeństwa w ochronie środowiska oraz o ocenach oddziaływania na środowisko występuje obowiązek sporządzania strategicznej oceny oddziaływania na środowisko. ${ }^{32}$ Art. 46 wspomnianej ustawy wymienia projekty dokumentów wymagających przeprowadzenia tej oceny. Są to projekty m.in. koncepcji przestrzennego zagospodarowania kraju, studium uwarunkowań i kierunków zagospodarowania przestrzennego gminy; polityk, strategii, planów bądź programów w dziedzinie przemysłu, transportu, energetyki, gospodarki wodnej, gospodarki odpadami. ${ }^{33}$ Przyjmuje się, że ,strategiczna ocena oddziaływania na środowisko stanowi jeden z kluczowych instrumentów zrównoważonego rozwoju". ${ }^{34}$ Natomiast głównym celem sporządzania strategicznej oceny oddziaływania na środowisko jest wypracowanie relacji między ochroną środowiska a rozwojem gospodarczo-społecznym, które będzie realizowało zasady wynikające z koncepcji zrównoważonego rozwoju. Wojewódzki Sąd

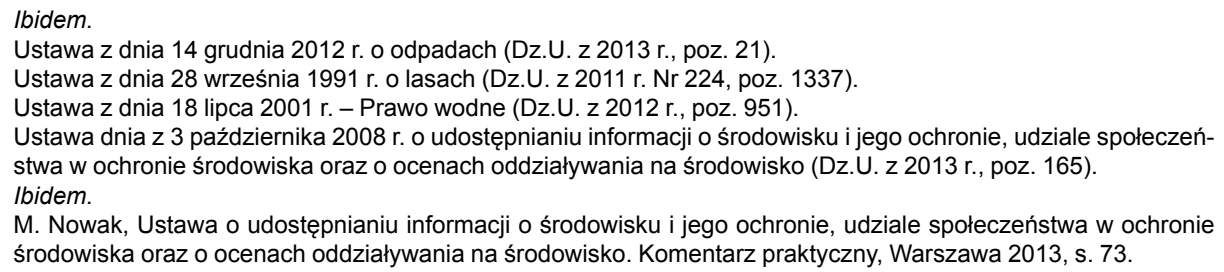


Administracyjny w Warszawie określił, że kwestie związane z działaniami podejmowanymi na rzecz ochrony środowiska są właśnie wyznaczane przez zasadę zrównoważonego rozwoju. ${ }^{35}$

Zrównoważony rozwój stanowi także podstawę działań organów administracji publicznej podejmowanych na podstawie ustawy o planowaniu i zagospodarowaniu przestrzennym. ${ }^{36}$ Statuuje o tym art. 1 ust. 1 ustawy. Organy administracji publicznej, upoważnione do sporządzania studium uwarunkowań i kierunków zagospodarowania przestrzennego czy miejscowego planu zagospodarowania przestrzennego, są zobowiązane do uwzględniania zasad i stanu ochrony środowiska, przyrody. ${ }^{37}$

Ochrona przyrody, ukształtowana w ustawie o ochronie przyrody, także wypełnia postulaty zawarte $\mathrm{w}$ zasadzie zrównoważonego rozwoju. Poprzez podejmowane, na mocy ustawy o ochronie przyrody, czynności administracji publicznej ma dojść m.in. do utrzymania procesów ekologicznych, stabilności systemów, zachowania różnorodności biologicznej czy dziedzictwa geologicznego. ${ }^{38}$

W najważniejszym polskim akcie poświęconym ochronie środowiska, czyli w ustawie Prawo ochrony środowiska, już na wstępie widać, że zasada zrównoważonego rozwoju jest zasadą, wobec której konkretne działania podmiotów muszą być podporządkowane ${ }^{39}$ Wszelkie działania przedsiębrane w celu ochrony środowiska czy określania warunków korzystania z jego zasobów muszą następować z uwzględnieniem zasady zrównoważonego rozwoju. Ustawa ta obliguje, w art. 8, podmioty sporządzające polityki, strategie, programy lub plany dotyczące energetyki, gospodarki wodnej, gospodarki odpadami, przemysłu uwzględnienia zasady zrównoważonego rozwoju i zasad ochrony środowiska. ${ }^{40}$

Art. 71 ustawy Prawo ochrony środowiska dokładnie wskazuje na zasadę zrównoważonego rozwoju jako podstawę sporządzania i aktualizacji studiów uwarunkowań i kierunków zagospodarowania przestrzennego gmin oraz ich planów miejscowych, strategii rozwoju województw oraz ich planów zagospodarowania przestrzennego, a także do sporządzania koncepcji przestrzennego zagospodarowania kraju. ${ }^{41}$

Zasada zrównoważonego rozwoju - wypełniana racjonalnie - jest zasadą, dzięki której obecne i przyszłe pokolenia będą mogły korzystać ze środowiska naturalnego. Ma ona niezaprzeczalny wpływ na stanowienie prawa. Zawarta w wielu aktach prawnych również niewątpliwie wpływa na podejmowanie określonych działań przez organy administracji publicznej.

\footnotetext{
35 Wyrok Wojewódzkiego Sądu Administracyjnego z 23 czerwca 2009 r., Sygn. akt IV SA/Wa 1269/08.

36 Ustawa z dnia 10 maja 2003 r. o planowaniu i zagospodarowaniu przestrzennym (Dz.U. 2013, poz. 21).

37 Ibidem.

38 Ustawa z dnia 16 kwietnia 2004 r. o ochronie przyrody (Dz.U. z 2013 r., poz. 165).

39 Ustawa z dnia 27 kwietnia 2001 r. Prawo ochrony środowiska (Dz.U. z 2008 r. Nr 25, poz. 150).

40 Ibidem.

41 Ibidem.
} 
Na podstawie przedstawionych jedynie kilku najważniejszych, z punktu widzenia ochrony środowiska, aktów prawnych i wynikających z nich zadań organów administracji publicznej należy uznać, że teza, wskazująca na zasadę zrównoważonego rozwoju jako dyrektywę działań administracji publicznej, nie jest bezzasadna.

\section{BIBLIOGRAFIA}

Banaszak B., Konstytucja Rzeczypospolitej Polskiej. Komentarz, Warszawa 2012.

Borys T., Wskaźniki ekorozwoju, Białystok 1999.

Ciechanowicz-McLean J., Prawo i polityka ochrony środowiska, Warszawa 2009.

Garlicki J., Konstytucja Rzeczypospolitej Polskiej. Komentarz. t. 5, Warszawa 2007.

Grabowska S., Grabowski R., Skrzydło W., Konstytucja RP: komentarz encyklopedyczny, Warszawa 2009.

Jendrośka J., Leksykon prawa ochrony środowiska, Warszawa 2012.

Mazur-Wierzbicka E., Ochrona środowiska a integracja europejska: doświadczenia polskie, Warszawa 2012.

Nowak M., Ustawa o udostępnianiu informacji o środowisku i jego ochronie, udziale społeczeństwa w ochronie środowiska oraz o ocenach oddziaływania na środowisko. Komentarz praktyczny, Warszawa 2013.

Piontek B., Koncepcja zrównoważonego rozwoju i trwałego Polski, Warszawa 2002. 


\section{THE PRINCIPLE OF SUSTAINABLE DEVELOPMENT AS A DIRECTIVE ON ACTIONS OF PUBLIC ADMINISTRATION}

The principle of sustainable development undoubtedly determines specific actions taken by organs of public administration.

Since the second half of 20. Century, this principle exerts a significant influence on international actions concerting the relation between economy, society and the environment.

The principle, gaining popularity, is defined in several publications, international certificates and in the Polish legal order, as well.

The Constitution of the Republic of Poland and numerous acts point that undertaking particular actions organs of public administration should, or even have to follow this principle of sustainable development.

Keywords: the principle of sustainable development, sustainable development, environment, public administration 